\title{
Sudden Death Caused by Clostridium perfringens Type D Enterotoxemia in Feedlot Cattle
}

\author{
Seong-Jun Jang, Sun-Hee Do', Mi-Ran Ki, I-Hwa Hong, Jin-Kyu Park, Yu-Jeong Cho, Ae Ri Ji, \\ Se-II Park, Sang-Joon Park, Tae-Hwan Kim, Dong-Mi Kwak and Kyu-Shik Jeong* \\ College of Veterinary Medicine, Kyungpook National University, Daegu 702-701, Korea \\ ${ }^{1}$ College of Veterinary Medicine, Konkuk University, Seaul 143-701, Korea
}

Received September 11, 2009 / Accepted May 14, 2010

\begin{abstract}
Sudden deaths have occurred in feedlot cattle with marked necro-hemorrhagic enteritis of the jejunum, ileum and colon. Suckling beef calves are the most frequently affected. Over-consumption of large amounts of milk, inadequate colostrum intake, chilling and stress are conducive to the development of enterotoxemia. Enterotoxemia caused by Clostridium perfringens type D mostly occurs following a sudden change of diet, particularly to feeds made richer in order to grow the cattle to market weight in feedlots. During July 2006, sudden deaths of cattle occurred in the Youngcheon regional area of Gyeongbuk province. There were no significant clinical signs except anorexia, depression, intermittent diarrhea and mild respiratory failure. Histological findings revealed a prominent intranuclear inclusion as well as infiltration of the globular leukocytes in various organs including the heart, kidneys, liver, spleen and lymph nodes. Spleen and lymphatic tissues showed lymphatic necrosis and a starry sky appearance. In the submucosa of the small intestines, basophilic aggregation was detected with massive infiltration of the globular leukocytes and eosinophils. Gram staining for the tissue sections containing inclusions of the small intestines revealed a positive histochemical reaction. Taken together, we suggest that Clostridium perfringens type D-induced enterotoxemia is determined to be the cause of sudden death of feedlot cattle.
\end{abstract}

Key words : Feedlot cattle, Clostridium perfringens, enterotoxemia, intranuclear inclusion, sudden death

\section{Introduction}

Enterotoxemia caused by Clostridium perfringens in cattle, is sometimes referred to as "sudden death" or "sudden death syndrome". It implies that the animal was normal a short time before and then died in the space of an hour or two. The reason for these deaths is thought to be a toxemia produced by toxins of $C$. perfringens, a group of organisms multiplying in the gut under certain conditions [16]. Some easily identified causes of sudden deaths include atypical interstitial pneumonia, choking, acute tracheal edema, ruptured abscesses and systemic clostridial disease [4]. Pierson et al. examined animals that feedlot personnel had classified as sudden deaths and suggested that $47 \%$ of the sudden deaths were the result of respiratory disease, bloating and acidosis $(20 \%)$, enteritis $(9 \%)$, a riding injury $(8 \%)$, pulmonary aneurysms (4\%), and brisket disease (6\%) [12]. Jenson and Mackey listed some specific diseases including enterotoxemia, acute indigestion or acidosis and bloating as causes of sudden

*Corresponding author

Tel : +82-53-950-5975, Fax : +82-53-950-5955

E-mail : jeongks@knu.ac.kr death syndrome [6].

Bovine enterotoxemia is an acute to per-acute syndrome occurring mainly in calves and characterized by the sudden or very rapid death of the calf with colic convulsions and nervous disorders as clinical signs. $C$. perfringens strains are classified into five groups according to their specific toxins as follows; type $A$ ( $a$-toxin), type $B(\alpha-, \beta$-and $\varepsilon$-toxin), type $C$ ( $a$-and $\beta$-toxin), type $D$ ( $a$-and $\varepsilon$-toxin), type $E$ ( $a$-and 1 -toxin), type AE (a-and enterotoxin) [16]. Enterotoxin produced by $C$. perfringens type $\mathrm{D}$ causes enterotoxemia, a highly lethal disease in sheep, goat and other animal species [10]. Enterotoxemia caused by type D mostly occurs following a sudden change of diet, particularly to feeds rich in order to grow to market weight in feedlots $[17,18]$. Biological effects of these toxins include necrotizing action and marked increase in capillary permeability [19]. Laboratory diagnosis depends on the demonstration of various toxins in the intestinal contents and bloodstream of fresh specimens and overgrowth of $C l$. perfringens organisms in the intestine [15]. The toxins of $C$. perfringens are detected and identified by serum-neutralization tests in mice and guinea pigs [5]. A polymerase chain reaction (PCR) has been 
applied for detection of low copy numbers of genes [19]. Immunohistochemistry represents a possible diagnostic alternative in those cases in which bacterial culture and PCR typing are not feasible. In this report, we demonstrated the identification of cattle enterotoxemia based on the histology and histochemical findings of $C$. perfringens type $\mathrm{D}$ that was a common cause of sudden death in feedlot cattle [4].

\section{Materials and Methods}

During July 2006, sudden deaths of cattle occurred in Youngcheon county, Gyeongbuk province. All the dead adult cattle $(n=6 ; 3-6$ yr.) and calves $(n=3 ; 6$ mo. -1 yr.) were being fed leftover food from local restaurants. The most common clinical signs were anorexia, depression, intermittent diarrhea and mild respiratory failure. During necropsy, severe hemorrhagic small intestines and colon were observed. The mesenteric lymph nodes and edematous lungs showed also severe hemorrhages. Formalin-fixed tis- sues including the kidneys, liver, lungs, spleen, heart, pancreas, parotid gland, supramammary lymph node, mesenteric lymph node, small intestine and large intestine, were submitted to the Laboratory of Pathology, College of Veterinary Medicine in Kyungpook National University for histopathological examination.

Histologic sections of formalin-fixed tissues, stained with hematoxylin and eosin (H\&E), were examined microscopically for all 9 cases, respectively. Machiavello stain and Gram stain applied to the significant lesions detected tissues.

\section{Results}

Histological findings revealed pulmonary congestion and hemorrhage, necrotic intestinal mucosa accompanied with hemorrhages and congestion, and also increased globular leukocytes within the bronchial epithelium showing mild pneumonia. Intranuclear inclusions as well as infiltration of the globular leukocytes were prominent in various organs
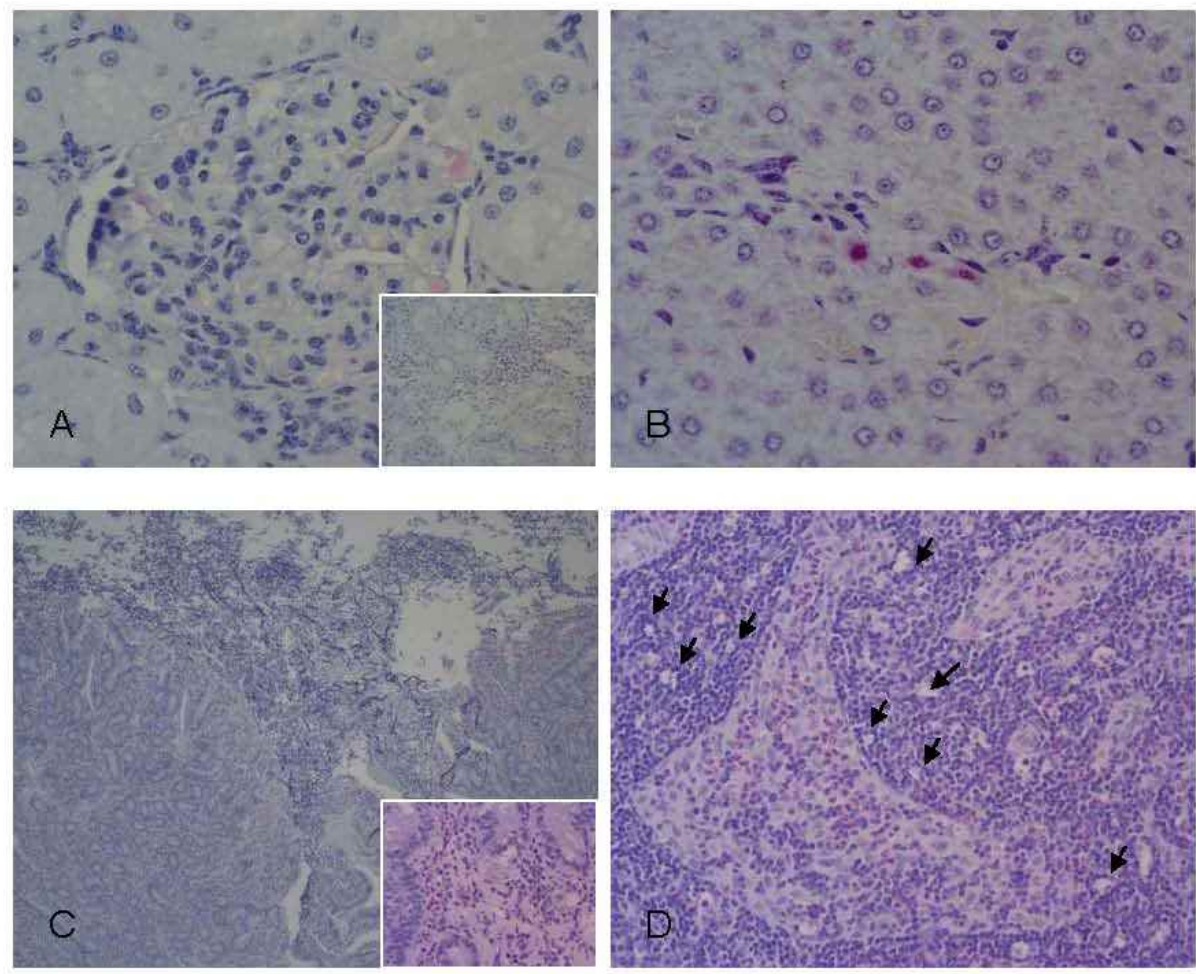

Fig. 1. Histopathological findings I. The glomeruli contained hyperchromatic cells with eosinophilic cytoplasm. Inset showed tubular degeneration and interstitial infiltrates of globular leukocytes. HE, $\times 200$, inset, $\times 100$ (Fig. 1A). Multifocal inflammation was detected in the liver. Eosinophilic and granular cytoplasmic cells were infiltrated with other inflammatory cells. Machiavello stain. $\times 100$ (Fig. 1B). The mucous of small intestines showed desquamation of epithelial cells in the lumen forming basophilic aggregations. Submucosa and lamina propria were also invaded by the globular leukocytes and eosinophils like the kidney. $\mathrm{HE}, \times 40$, inset, $\times 100$ (Fig. 1C). Globular leuokocytes infiltrates were detected in the lymph node. The supramammary lymph node and parotid gland also revealed a depletion of lymphocytes and prominent starry sky appearance. HE, $\times 100$ (Fig. 1D). 
including the heart, kidney, liver, spleen and lymph nodes. The spleen and lymphatic tissues showed lymphoid necrosis and a starry sky appearance. The kidney revealed tubular and glomeruli degeneration with interstitial infiltrates of globular leukocytes (Fig. 1A). Multi-focal inflammation with eosinophilic granular cytoplasmic cells with mononuclear inflammatory cells was detected in the liver (Fig. 1B). Mucus of the small intestines had basophilic aggregation with massive infiltration of the globular leukocytes and eosinophils in the submucosa layer. Lamina propria was also invaded by the globular leukocytes and eosinophils like the kidney. Gram staining for the tissue sections containing inclusions and the small intestines revealed highly positive reaction (Fig. 1C). Globular leuokocytes infiltrates were detected in the most of lymph node; moreover the supramammary lymph node and parotid gland revealed depletion of lymphocytes and a prominent starry sky appearance (Fig. 1D). Machiavello staining for the supramammary gland and parotid gland sections showed various types of intracytoplasmic inclusions (Fig. 2A-a, 2A-b). Gram positive bacterias were diffusely infiltrated in the glomeruli and tubular epitheliums of kidney (Fig. 2B, white dotted circles), and in- testinal mucosa (Fig. 2C, arrow).

\section{Discussion}

For many years, sudden deaths or the sudden death syndrome have been perceived as major concerns among cattle owners and veterinarians in Kyeongbuk province [7]. The local government set up a subcommittee to investigate the disease and take preventive measures. The major problems were that the cattle generally died of sudden recumbency with convulsions following anorexia, depression, ataxia, muscular tremor, tachycardia and dyspnea without any premonitory symptoms. Epidemiological surveys showed no causative agents such as related pesticide, fertilizer, or chemical drugs. Macroscopically, there were coagulation disorder in the abdominal cavity, and edematous hemorrhagic lung, and watery blood-tinged contents of the small intestine. All of the above gross lesions were compatible match with histopathologic findings. Microbiologically, Cl. perfringens were detected from the small intestinal contents, toxins were identified as $\mathrm{Cl}$. perfingens type D toxin, and the cause of sudden deaths was proved to be enterotoxemia. The pathogenic tests
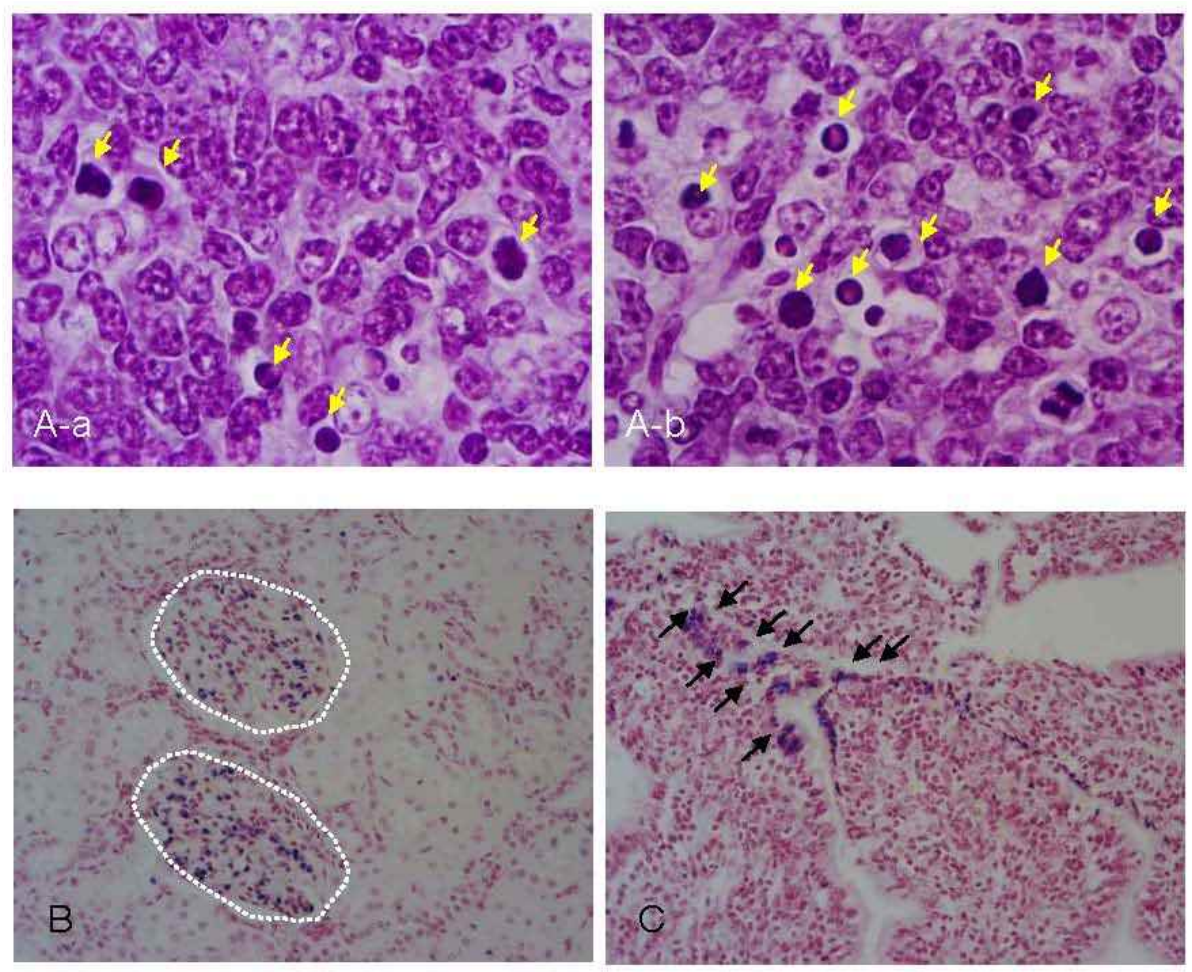

Fig. 2. Histopathological findings $\Pi$. The supramammary gland (Fig. 2A-a) and parotid gland (Fig. 2A-b) showed various types of intracytoplasmic inclusions (arrow). Machiavello, $\times 100$. Gram positive bacteria diffuse infiltrated in the glomeruli and tubular epithelium (white dotted circles). Gram staining, $\times 100$ (Fig. 2B). The intestinal mucosa also showed a gram positive reaction in the mucous (arrow). Gram staining, $\times 100$ (Fig. 2C). 
of mice and goats inoculated with $C$. perfringens toxin have been demonstrated to be similar to the results of natural cases [3].

The useful method to prevent enterotoxemia of feedlot cattle was a dietary administration of antibiotics and probiotics $[2,8]$. Thereafter, it occurred sporadically and the incidence rate was reduced but the pathogenesis is still unknown. In this report, we tried to find out the histological changes of enterotoxemia based on the histology and histochemical findings of $C$. perfringens type D. Histological findings revealed prominent intranuclear inclusions as well as infiltration of the globular leukocytes in various organs including the heart, kidney, liver, spleen and lymph nodes in our case. Gram staining for the tissue sections containing inclusions and the small intestines revealed positive histochemical reactions like previously reported [1]. The disease by $C$. perfringens largely depends on the toxins having each pharmacological action cumulative in producing the final effect. There were differences in the changes caused by all three types of the $C$. perfringens in cattle, which made it possible to distinguish them as causative agents. Cl. perfringens type A induced slight icterus and a slightly manifested hemosiderosis of the liver, kidneys and spleen; $C$. perfringens type D was responsible for severe injuries, hyaline dystrophy and a pulpy disease of the kidneys and CNS toxicity; Cl. perfringens type $\mathrm{C}$ caused necrotic enteritis, pronounced hemorrhagic diathesis, degenerative changes in the ganglial cells, and demyelinization of the brain $[9,11,14]$. The $C$. perfringens type $\mathrm{D}$ epsilon-toxin causes a severe enterotoxaemia characterized by cardiac, pulmonary, kidney and brain edema [14]. Experimentally, epsilon-toxin causes lethality in the mouse intravenous injection model [13].

Enterotoxemia development is pre-acute in most cases and treatment is possible only in very rare cases. The most practical way to handle $C$. perfringens related illnesses is to prevent them. To combat the disease, however, accurate detection of $C$. perfringens and diagnosis of the lesions of affected animals as well as anti-bacterial agent such as vaccines against type $\mathrm{D}$ toxin are needed. Our histological manifestation may help to identify the type D enterotoxemia and treat the disease thereafter.

In summary, histological findings showed prominent intranuclear inclusion bodies and infiltration of the globular leukocytes in various organs and lymphatic necrosis and a starry sky appearance in spleen and lymphatic tissues. Basophilic aggregation, coupled with massive infiltration of the globular leukocytes and eosinophils and positive responses for Gram staining in the tissue sections of small intestine were observed. On the bases of the results, $\mathrm{Cl}$. perfringens type D induced enterotoxemia may be a cause of sudden death of feedlot cattle in Youngcheon province.

\section{Acknowledgement}

This research was supported by a grant (CBM 31-B3003-01-01-00) from the Center for Biological Modulators of the $21^{\text {st }}$ Century Frontier R\&D Program, the Ministry of Science and Technology, Korea.

\section{References}

1. Bacciarini, L. N., P. Boerlin, R. Straub, J. Frey, and A.Grone. 2003. Immunohistochemical Localization of Clostridium perfringens b2-toxin in the Gastrointestinal Tract of Horses. Vet. Pathol. 40, 376-381.

2. Becker, P. M. 2005. Physiological Achilles'heels of enteropathogenic bacteria in livestock. Curr. Issues. Intestinal Microbiol. 6, 31-54.

3. Fairley, R. A. 2005. Lesions in the brains of three cattle resembling the lesions of enterotoxaemia in lambs. $N$. Z. Vet. J. 53, 356-358.

4. Glock, R. D. and B. D. De Groot. 1998. Sudden Death of Feedlot Cattle. J. Anim Sci. 76, 315-319.

5. Hortin, R. E., D. L. Madden, and N. B. McCullough. 1970. Pathogenecity of Clostridium perfringens for Germ-Free Guinea Pigs After Oral Ingestion. Appl. Microbiol. 19, 314-316.

6. Jensen, R. and D. R. Mackey. 1971. Diseases of Feedlot Cattle. $2^{\text {nd }}$ Ed. Lea and Febiger, Philadelphia, PA. pp. 135, 284, 292.

7. Jyeong, J. S., N. C. Park, J. H. Kim, Y. H. Kim, K. H. Cho, M. H. Cho, J. K. Son, and Y. W. Kim. 1999. Study on etiological agents of sudden death in cattle at the region of Sarari in Korea. Korean J. Vet. Serv, 22, 325-347.

8. Krehbiel, C. R., R. G. Zhang, and S. E. Gilliland. 2003. Bacterial direct-fed microbials in ruminant diets: Performance response and mode of action. J. Anim Sci. 81(E. Suppl. 2), E120-E132.

9. Lulov, R. and A. K. Angelov. 1986. Enterotoxemia in newborn calves due to Cl. Perfringens types A, C and D. Vet. Med Mauki. 23, 20-28.

10. Niilo, L. 1980. Clostridium perfringens in animal disease: A review of current knowledge. Can. Vet. J. 21, 141-148.

11. Niilo, L. 1987. Toxigenic characteristics of clostridium perfringens type $\mathrm{C}$ in enterotoxemia of domestic animals. Can. J. Vet. Res. 51, 224-228.

12. Pierson, R. E., R.Jensen, L. H.Lauerman, D. A.Saart, P. M.Braddy, A. E. McChesney, and D. P. Horton. 1976. Sudden deaths in yearling feedlot cattle. J. Am Vet. Med 
Assoc. 169, 527-529.

13. Sayeed, S., M. E. Fernandez-Miyakawa, D., J. Fisher, V. Adams, R. Poon, F. A. Uzal, and B. A. McClane, 2005. Epsilon-Toxin is required for most Clostridium perfringens type $\mathrm{D}$ vegetative culture supernatants to cause lethality in the mouse intravenous injection model. Infect. Immun. 73, 7413-7421.

14. Songer, J. G. 1996. Clostridial enteric diseases of domestic animals. Clin. Microbiol. Rev. 9, 216-234.

15. Thomson, R. G., D. A. Barnum, and P. R. Ide. 1968. The significance of some clostridial organism in the liver of domestic animal at post mortem. Can. Vet. J. 9, 263-268.

16. Timoney, J. F., H. Gillespie, F. W. Scott, and J. E. Barlough.
1988. Hagan and Bruner's microbiology and infectious diseases of domestic animals. $8^{\text {th }} \mathrm{Ed}$. Comstock Publishing Association. London. 359-401

17. Uzal, F. A. and J. G. Songer. 2008. Diagnosis of Clostridium perfringens intestinal infections in sheep and goats. J. Vet. Diagn. Invest. 20, 253-265.

18. Uzal, F. A. and W. R. Kelly. 1998. Experimental Clostridium perfringens type D enterotoxemia in goats. Vet. Pathol. 35,132-140.

19. Yoo, H. S., S. E. Lee, K. Y. Park, and Y. H. Park. 1997. Molecular typing and epidemiological survey of prevalence of clostridium perfringens types by multiplex PCR. J. Clin. Microbiol. 35, 228-232

\section{초록 : 비육 우의 Clostridium perfringens $\mathrm{D}$ 형 장독 혈증에 의한 폐사}

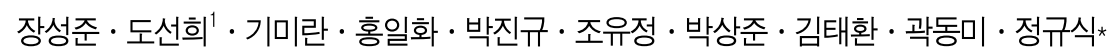

(경북대학교 수의과대학, ${ }^{1}$ 건국대학교 수의과대학)

비육우의 공장, 회장 및 결장의 특징적 괴사 출혈성 장염 증상은 폐사 증후군과 관련이 있는 것으로 인식되고 있다. 특히 젖먹이 송아지들이 폐사 증후군에 가장 영향을 받는데, 포유시 송아지에게 과식을 시키거나, 비위생적 초유 급유, 체온 하강 및 스트레스는 장독혈증 발생의 원인들이다. 2006년 7월 중 경북 영천 지역에서 축우의 폐사가 발생하였다. 식욕부진, 의기소침, 간헐적인 설사 및 경미한 호흡 곤란을 제외하고는 특별한 임상 증상은 없었으나, 조직학적 소견에 의하면, 심장, 신장, 간, 비장 및 임파선을 포함한 각종 기관에서 globular leukocytes 의 침윤뿐 아니라 핵내 봉입체가 현저하게 나타났다. 비장과 림프조직에서는 림프 괴사와 림프구 괴사로 인한 'starry sky appearance'를 나타내었다. 소장 점막 하에서는 다량의 globular leukocytes와 호산 구의 침윤과 함께 호 염기성 세포 집단이 관찰되었다. 봉입체가 있는 소장 조직의 단면은 그램 염색에 대해 조직 화학적으로 양성 반응을 나타내었다. 결론적으로, 비축우의 폐사 원인은 조직학적 및 조직화학적 분석 결과를 근거로 Clostridium perfringens $\mathrm{D}$ 형균에 의한 장독혈증으로 진단되었다. 